\title{
Viable, lyophilized lactobacilli do not increase iron absorption from a lactic acid-fermented meal in healthy young women, and no iron absorption occurs in the distal intestine
}

\author{
Stine Bering ${ }^{1}$, Laila Sjøltov ${ }^{1}$, Seema S. Wrisberg ${ }^{1}$, Anna Berggren ${ }^{2}$, Jan Alenfall ${ }^{2}$, Mikael Jensen $^{3}$, \\ Liselotte Højgaard $^{4}$, Inge Tetens ${ }^{5}$ and Klaus Bukhave ${ }^{1}$ \\ ${ }^{1}$ Department of Human Nutrition, University of Copenhagen, Frederiksberg C, Denmark \\ ${ }^{2}$ Probi AB, Ideon Gamma 1, Lund, Sweden \\ ${ }^{3}$ Radiation Research Department, Ris $\phi$ National Laboratory, Roskilde, Denmark \\ ${ }^{4}$ PET and Cyclotron Unit, The National University Hospital, Copenhagen, Denmark \\ ${ }^{5}$ The National Food Institute, The Technical University of Denmark, S $\phi b o r g$, Denmark
}

(Received 20 November 2006 - Revised 19 April 2007 - Accepted 20 April 2007)

\begin{abstract}
Lactic acid-fermented foods have been shown to increase Fe absorption in human subjects, possibly by lowering pH, activation of phytases, production of organic acids, or by the viable lactic acid bacteria. In this study the effect of a heat-inactivated lactic acid-fermented oat gruel with and without added viable, lyophilized Lactobacillus plantarum 299v on non-haem $\mathrm{Fe}$ absorption was investigated. Furthermore, Fe absorption in the distal intestine was determined. In a randomized, double-blinded crossover trial eighteen healthy young women aged 22 (SD 3 ) years with low Fe status (serum ferritin $<30 \mu \mathrm{g} / \mathrm{l}$ ) were served the two test gruels, extrinsically labelled with ${ }^{59} \mathrm{Fe}$ and served with two enterocoated capsules (containing ${ }^{55} \mathrm{Fe}$ (II) and ${ }^{55} \mathrm{Fe}$ (III), respectively) designed to disintegrate in the ileum. The meals were consumed on two consecutive days, e.g. in the order AA followed by BB in a second period. Non-haem Fe absorption was determined from ${ }^{59} \mathrm{Fe}$ whole-body retention and isotope activities in blood samples. The concentrations of Fe, lactate, phytate, and polyphenols, and the $\mathrm{pH}$ were similar in the heat-inactivated lactic acid-fermented oat gruels with and without added L. plantarum $299 \mathrm{v}$, and no difference in Fe absorption was observed between the test gruels (1.4 and $1.3 \%$, respectively). Furthermore, no absorption of Fe in the distal intestine was observed. In conclusion, addition of viable, lyophilized lactobacillus to a heat-inactivated lactic acid-fermented oat gruel does not affect Fe absorption, and no absorption seems to occur in the distal part of the intestine from low Fe bioavailability meals in these women.
\end{abstract}

Non-haem iron absorption: Human subjects: Lactic acid bacteria: Organic acids: Colon

Meals with lactic acid-fermented vegetables and cereals have shown a significant increase in Fe absorption in human subjects $^{1-4}$. This increase may be caused mainly by the small organic acids that are produced during the lactic acid fermentation, with lactic acid as the major product. Lactic acid may act by (a) lowering $\mathrm{pH}$, which activates endogenous phytases present and consequently releases Fe from insoluble $\mathrm{Fe}-$ phytate complexes ${ }^{5}$, (b) increasing the buffer capacity in the $\mathrm{pH}$ range 3-5, which keep $\mathrm{Fe}$ in a bioavailable form $^{3}$, (c) formation of soluble Fe-ligand complexes at intestinal $\mathrm{pH}^{6}$, and (d) delaying the gastric emptying rate $^{7}$, which increases the time that dietary Fe is in contact with the duodenal surface.

$\mathrm{Fe}$ absorption is believed to occur mainly in the duodenum and to diminish from the proximal jejunum to the ileum ${ }^{8}$. However, the distal part of the intestine may also play an important role in the absorption of $\mathrm{Fe}^{9-11}$. Animal studies have shown a significant increase in $\mathrm{Fe}$ absorption in the proximal colon compared to the ileum on a surface basis. Due to the larger surface area of the human colon compared to the duodenum, and the longer retention time in the colon, the colon may add significantly to the absorption of $\mathrm{Fe}^{9}$. Although very little is known about the mechanisms of $\mathrm{Fe}$ absorption in the colon, animal studies indicate that the colonic mucosa is highly permeable for $\mathrm{Fe}$ both via active transport and passive diffusion ${ }^{10}$. The luminal $\mathrm{pH}$, the caecal surface area, and the concentration of organic acids in the colon are closely associated with the quantities of fermentable carbohydrates (prebiotics), as well as mineral concentrations ${ }^{12}$; thus, microbial fermentation could play a major role in $\mathrm{Fe}$ absorption from the colon ${ }^{13}$. Ingestion of prebiotics, in form of non-digestible oligosaccharides that stimulate fermentation by the intestinal flora, have been shown to increase Fe absorption in rats ${ }^{14,15}$, but this effect has so far not been confirmed in human subjects ${ }^{16,17}$. An increase in Fe absorption from probiotic foods has also been shown in rats ${ }^{9,18}$, and the effect has been addressed both to the fermentation products and to the viable bacteria ${ }^{9}$. However, the rat is not an optimal model for

Abbreviations: DcytB, duodenal cytochrome B.

* Corresponding author: Dr Stine Bering, fax +45 35332483, email sbs@life.ku.dk 
human Fe absorption, since they are able to synthesize ascorbic acid and possess phytase activity in the intestinal lumen ${ }^{19}$.

A probiotic non-dairy food product based on oatmeal fermented with the defined probiotic strain L. plantarum $299 \mathrm{v}$ (Probi AB, Lund, Sweden) has shown several of the health benefits attributed to probiotics ${ }^{20}$. The strain originates from the human intestinal mucosa and has been shown to survive the low $\mathrm{pH}$ of the stomach, to tolerate the bile salts in the small intestine, and to colonize the intestinal mucosa, including the jejunum, after oral administration ${ }^{21}$.

The objectives of the present study were to examine the effect of a heat-inactivated fermented oat gruel with added viable, lyophilized L. plantarum $299 \mathrm{v}$ on non-haem Fe absorption from a meal with low Fe bioavailability compared to the heat-inactivated fermented oat gruel without added viable L. plantarum $299 \mathrm{v}$. In addition, the study allowed for an investigation of the absorption of non-haem $\mathrm{Fe}$ in the ileum and colon separate from that occurring in the proximal small intestine. The study was designed as a randomized, double-blinded crossover trial with eighteen healthy young women.

\section{Subjects and methods}

\section{Subjects}

Eighteen women aged 22 (SD 3) years with a body weight of 64 (SD 7) $\mathrm{kg}$ and BMI of 21.9 (SD 1.9) $\mathrm{kg} / \mathrm{m}^{2}$ participated in the study. All subjects were non-smokers and were not pregnant or lactating, and none of the women took any vitamin or mineral supplements for $\leq 2$ months before and during the study. Fifteen subjects used oral contraceptives, but none of the subjects were routinely taking any other medication. Blood donation was not allowed for at least 2 months prior to and during the study. The participants were recruited from universities in the nearby area and received oral and written information about the study before they gave their written consent. The study was approved by the Municipal Ethical Committee of Copenhagen and Frederiksberg, Denmark (file no. KF 01-219/03), and the National Institute of Radiation Hygiene, Denmark, and was registered at the ClinicalTrials.gov database (NCT00283491).

\section{Experimental design}

The study was a randomized, double-blinded crossover trial, in which each subject was served two test meals: A, a heatinactivated lactic acid-fermented oat gruel with added lyophilized viable L. plantarum 299v and B, a heat-inactivated lactic acid-fermented oat gruel.

The non-haem Fe absorption from the two test meals was determined by extrinsic labelling of the oat gruels with ${ }^{59} \mathrm{Fe}$, while absorption from the distal part of the intestine was elucidated by ${ }^{55} \mathrm{Fe}$ in enterocoated capsules designed to disintegrate in the ileum. Each test meal was served within one of two periods separated by a wash-out period of $18 \mathrm{~d}$ to avoid any possible carry-over effect of the meal with the viable, colonizing L. plantarum $299 \mathrm{v}$, and the test meals were served twice on two consecutive mornings to minimize dayto-day variation. The subjects were assigned randomly to each of two groups, which were given meal A and B in different orders.
The retention of ${ }^{59} \mathrm{Fe}$ was measured in a whole-body counter at baseline and $15 \mathrm{~d}$ after intake of the test meals, and the activity of both isotopes, ${ }^{55} \mathrm{Fe}$ and ${ }^{59} \mathrm{Fe}$, was measured in a blood sample drawn $18 \mathrm{~d}$ after intake of the test meals ${ }^{22}$. Residual isotope activities from the first period were subtracted from the isotope activity levels in the second period and Fe excretion between the two measurements was assumed negligible.

The stability of the enterocoated capsules and therefore length of time before disintegration in the gastrointestinal tract was estimated from in vitro pepsin and pancreatin-bile digestions.

\section{Composition of test meals and serving procedure}

Probi AB (Lund, Sweden) supplied the oat gruels for the test meals. Whole grain oatmeal (Kungsörnen AB, Järna, Sweden) and water was mixed and a blend of different enzymes was added, followed by a specific heat treatment to reduce viscosity. The oat gruel was heated to $90^{\circ} \mathrm{C}$ for $1 \mathrm{~h}$ to inactivate the enzymes and to kill any contaminating microorganisms already present in the gruel, followed by inoculation with L. plantarum 299v (DSM 9843) ${ }^{23}$. After fermentation, the oat gruel was pasteurized $\left(100^{\circ} \mathrm{C}\right.$ for $1 \mathrm{~h}$, to kill the relatively heat resistant L. plantarum $299 \mathrm{v})$ and stored frozen $\left(-20^{\circ} \mathrm{C}\right)$ with a final DM of $15 \mathrm{~g} / 100 \mathrm{~g}$ (oat gruel B). The fermented oat gruel with viable L. plantarum $299 \mathrm{v}$ (A) was produced by inoculation of oat gruel $\mathrm{B}$ at $4{ }^{\circ} \mathrm{C}$ with viable lyophilized L. plantarum $299 \mathrm{v}\left(10^{9} \mathrm{cfu} / \mathrm{g}\right) 1 \mathrm{~d}$ before serving and stored at $4^{\circ} \mathrm{C}$ to minimize further fermentation and production of organic acids compared to the control gruel (B).

The enterocoated capsules were prepared the day before serving by filling hard gelatine capsules $(0.50 \mathrm{ml}$, Wepa, Hillscheid, Germany) with $250 \mathrm{mg}$ potato flour and adding either $28 \mathrm{kBq}{ }^{55} \mathrm{Fe}(\mathrm{II}) \mathrm{Cl}_{2}$ and $25 \mu \mathrm{g}$ ascorbic acid to avoid oxidation or ${ }^{55} \mathrm{Fe}(\mathrm{III}) \mathrm{Cl}_{3}$ (Risø National Laboratory, Roskilde, Denmark) in $25 \mu \mathrm{l} 0 \cdot 1 \mathrm{M}-\mathrm{HCl}$. The capsules were then coated with cellulose acetate phthalate by dipping each capsule half fixed to a disc eight times into the film solution $(1.0 \mathrm{~kg}$ cellulose acetate phthalate, $0.05 \mathrm{~kg}$ virgin castor oil, and $8.95 \mathrm{~kg}$ acetone $)^{24}$.

For each test meal $100 \mathrm{~g}$ oat gruel (A or B) plus two enterocoated capsules with ${ }^{55} \mathrm{Fe}$ (II) and ${ }^{55} \mathrm{Fe}(\mathrm{III})$, respectively, were served with a $140 \mathrm{~g}$ whole-wheat roll $(60.0 \mathrm{~g}$ wheat flour, $20.0 \mathrm{~g}$ whole-wheat flour, $2.0 \mathrm{~g}$ salt, $2.0 \mathrm{~g}$ yeast, $16.0 \mathrm{~g}$ rapeseed oil, $40.0 \mathrm{~g}$ ultra pure water) with $10 \mathrm{~g}$ butter and a glass of ultra pure water $(200 \mathrm{ml})$. The whole-wheat rolls were prepared in one batch, stored at $-20^{\circ} \mathrm{C}$ and reheated in an oven at $200^{\circ} \mathrm{C}$ for $10 \mathrm{~min}$ before serving.

The test meals were served in the morning after $12 \mathrm{~h}$ fasting. Intake of a maximum of 0.5 litre water was allowed overnight. Moderate or hard physical activity or the intake of alcohol was not allowed during the $12 \mathrm{~h}$ before intake of the test meals. After consuming the test meals, the subjects were not allowed to eat or drink for $2 \mathrm{~h}$ and intake of alcohol was prohibited for $24 \mathrm{~h}$. The subjects filled in a questionnaire in connection with each test meal to ensure that they adhered to all procedures, and they were instructed to eat and drink alternately and to rinse the glass containing the oat gruel thoroughly with the water to ensure complete intake of the isotope dose. A staff member ensured that the protocol was followed. 


\section{Isotopes and labelling procedure}

The oat gruels were extrinsically labelled by adding $1 \mathrm{ml}$ isotope solution $\left(57 \mathrm{kBq}{ }^{59} \mathrm{FeCl}_{3}\right.$ in $0 \cdot 1 \mathrm{M}-\mathrm{HCl}$ (Ris $\varnothing$ National Laboratory)] directly to the oat gruels $18 \mathrm{~h}$ before serving for isotope exchange.

\section{Dietary analyses}

The oat gruels and the bread were freeze-dried, homogenized, and analyzed in duplicates for total $\mathrm{Fe}, \mathrm{Ca}, \mathrm{Zn}$, phytate, and polyphenols. The energy content was calculated using a national food-composition database (Danish Tables of Food Composition, DANKOST 2000, version 1.20, Herlev, Denmark). Total $\mathrm{Fe}, \mathrm{Ca}$, and $\mathrm{Zn}$ were determined by atomic absorption spectrophotometry (Spectra-AA 200, Varian, Mulgrave, Australia) after wet-ashing in a MES 1000 Solvent Extraction System (CEM Corp., Matthews, NC, USA) with $650 \mathrm{~g}$ suprapure nitric acid/l (Merck KgaA, Darmstadt, Germany). A typical diet (Standard Reference Material 1548a, National Institute of Standards and Technology, Gaithersburg, MD, USA) was used as the reference for Fe (35.3 (SD 3.77) $\mu \mathrm{g} / \mathrm{g}$ ), Ca (1.96 (SD 0.11) $\mathrm{mg} / \mathrm{g}$ ), and $\mathrm{Zn}$ $(24.6(\mathrm{SD} 1.79) \mu \mathrm{g} / \mathrm{g})$, and the analysed values were $34.7 \mu \mathrm{g} /$ $\mathrm{g}, 1.83 \mathrm{mg} / \mathrm{g}$, and $23.3 \mu \mathrm{g} / \mathrm{g}$, respectively. Phytate was analyzed as individual inositol tri- to hexaphosphates by high-performance ion chromatography ${ }^{25}$. Polyphenols were analyzed as total polyphenols by the Folin-Ciocalteu method and as proanthocyanidines using the vanillin assay with sulphuric $\operatorname{acid}^{26}$, and the results expressed as $\mathrm{mg}$ gallic acid and $\mathrm{mg}(+)$ catechin equivalents, respectively. The concentration of organic acids in the oat gruels was determined by capillary gas chromatography ${ }^{27}$.

\section{Determination of Fe status}

Blood samples were drawn from the cubital vein after the subjects had rested for $10 \mathrm{~min}$ in a supine position. $\mathrm{Hb}$ analysis was carried out on blood $(3.5 \mathrm{ml})$ collected in tubes containing dissolved EDTA (Vacutainer system, Becton Dickinson, Franklin Lakes, NJ, USA) using a Sysmex KX-21 automated hematology analyzer (Sysmex America Inc., Mundelein, IL, USA) with appropriate controls (Eight check-3WP, 22490822, Sysmex America Inc.). Intra-assay and interassay variations were $0.5 \%(n 12)$ and $0.6 \%(n 27)$, respectively. Serum ferritin and $\alpha_{1}$-antichymotrypsin analyses were carried out on serum from blood $(5.0 \mathrm{ml})$ collected in plain tubes (Vacutainer system, Becton Dickinson). Ferritin was determined by a chemiluminescent immunometric assay using an Immulite 1000 analyzer (Diagnostic Products Corporation, Los Angeles, CA, USA) with appropriate reference sera (3rd International standard for ferritin (80/578);WHO, NIBSC, South Mimms, UK). Intra-assay and inter-assay variations were $2.7 \%(n 15)$ and $5.0 \%$ ( $n$ 15), respectively. $\alpha_{1}$-Antichymotrypsin was determined by an immunoturbidimetric technique using a Cobas Mira analyzer (Roche Diagnostic Systems, F. Hoffman-La Roche Ltd., Basel, Switzerland) with appropriate reference sera (European Commission certified reference material 470, no. 11924, IRMM, Geel, Belgium). Intra-assay and inter-assay variations were $1.4 \%(n 12)$ and $3.2 \%(n 14)$, respectively.

\section{Determination of non-haem Fe absorption}

Activities of ${ }^{55} \mathrm{Fe}$ and ${ }^{59} \mathrm{Fe}$ were determined as double determinations from blood samples $(2 \times 20 \mathrm{ml})$ collected in tubes containing heparin as anticoagulant (Vacutainer system, Becton Dickinson) by dry-ashing followed by recrystallization and solubilization before counting in a Tricarb 2100TR Liquid Scintillation Analyzer (Packard Instruments, Meriden, CT, USA) with automatic quench correction as described previously $^{22}$. The whole-body retention of ${ }^{59} \mathrm{Fe}$ was measured in a lead-lined steel chamber with 4 NE110 plastic scintillator blocks (Nuclear Enterprises Ltd, Edinburgh, UK) connected to conventional nuclear electronic modules and a multichannel analyzer system. The counting efficiency and energy window settings were established through measurements of water-filled phantoms whose outlines and weights were approximately equal to those of human subjects. The phantoms were filled with known concentrations of the isotope. In the actual setup and with the energy window used, the overall counting efficiency for ${ }^{59} \mathrm{Fe}$ evenly distributed in a $77 \mathrm{~kg}$ phantom was approximately $20 \%$. To minimize the contamination by atmospheric background activity, all subjects had a shower, washed their hair, and were dressed in hospital clothing before each measurement. The counting time was $10 \mathrm{~min}$, and the results were corrected for chamber background radiation and for the individual background radiation level of the subjects, which was determined $1 \mathrm{~d}$ before beginning of the first intervention period. All results from determination of radioactivity were corrected for the physical decay of the isotope. Fe absorption data are expressed as ${ }^{59} \mathrm{Fe}$ wholebody retention measured directly from whole-body counting and as ${ }^{55} \mathrm{Fe}$ whole-body retention determined from the relative activities of ${ }^{55} \mathrm{Fe}$ and ${ }^{59} \mathrm{Fe}$ in blood and the ${ }^{59} \mathrm{Fe}$ whole-body retention using the following equation, which is based on the assumption that the fractions of ${ }^{55} \mathrm{Fe}$ and ${ }^{59} \mathrm{Fe}$ in blood are similar ${ }^{28}$ :

$$
\begin{aligned}
{ }^{59} \mathrm{Fe} \text { absorption }(\%)= & {\left[\left({ }^{55} \mathrm{Fe} \text { activity in blood } /{ }^{55} \mathrm{Fe} \text { dose }\right)\right.} \\
& \times\left({ }^{59} \mathrm{Fe} \text { whole body activity } /\right. \\
& \left.\left.{ }^{59} \mathrm{Fe} \text { activity in blood }\right)\right] \times 100 \%
\end{aligned}
$$

\section{Stability of ${ }^{55} \mathrm{Fe}(\mathrm{II})$ in enterocoated capsules}

The stability of ${ }^{55} \mathrm{Fe}$ (II) in the enterocoated capsules was determined by separation of the $\mathrm{Fe}$ according to oxidation states by paper chromatography ${ }^{29}$. Capsules from the same batch as given in the intervention period were analyzed following $7 \mathrm{~d}$. The ${ }^{55} \mathrm{Fe}$ (II)-capsules were cut through with a scalpel under $8 \mathrm{ml}$ water and the content was mixed with the water in the closed container. After $2 \mathrm{~d}$ aliquots were taken from the supernatants for determination of ${ }^{55} \mathrm{Fe}$ (III) by paper chromatography. Briefly, Whatman filter paper (no. 1, Whatman Inc., Florham Park, NJ, USA) was washed with $1 \mathrm{M}-\mathrm{HCl}$ and dried followed by application of $20 \mu \mathrm{l}$ sample. Upward chromatography was carried out with equal volumes of butanol, acetic acid, and ethanol (Merck) as eluant in a closed container and allowed to develop approximately $16 \mathrm{~cm}$. After drying, the paper was scanned for $2 \mathrm{~h}$ on a TLC analyzer (miniGita scanner, Raytest Inc., Wilmington, NC, USA). 
The original solutions of ${ }^{55} \mathrm{Fe}(\mathrm{II})$ and ${ }^{55} \mathrm{Fe}(\mathrm{III})$ in $0 \cdot 1 \mathrm{M}-\mathrm{HCl}$ (Risø National Laboratory) were used as references. The detection limit was approximately $160 \mathrm{dpm}$.

\section{In vitro digestion of enterocoated capsules}

Enterocoated capsules filled with either ${ }^{55} \mathrm{Fe}$ (II) and ${ }^{55} \mathrm{Fe}$ (III) as described or the water-soluble marker $\left[{ }^{14} \mathrm{C}\right]$ mannitol $(19 \mathrm{kBq}, 2 \cdot 1 \mathrm{GBq} / \mathrm{mmol}$, PerkinElmer Life and Analytical Sciences, Boston, MA, USA) were digested in vitro with the oat gruels by adding the capsule to a mixture of $50 \mathrm{ml}$ oat gruel (A and $\mathrm{B}$, respectively) and $50 \mathrm{ml}$ pepsin solution $(9.1 \mathrm{ml} 5 \mathrm{mg}$ porcine pepsin/ml, 1,100 units $/ \mathrm{mg}$ protein, Sigma-Aldrich, St. Louis, MO, USA, in $50 \mathrm{~mm}$-acetic acid buffer (Sigma-Aldrich), $\mathrm{pH} 4.5$, and $40.9 \mathrm{ml}, 50 \mathrm{~mm}-\mathrm{HCl}$ (Riedel-de-Haën, Seelze, Germany)). The solutions were incubated on a shaking water bath $\left(37^{\circ} \mathrm{C}\right)$ and aliquots $(100 \mu \mathrm{l})$ were taken every $30 \mathrm{~min}$ for liquid scintillation counting. After $4 \mathrm{~h}$ the capsules were removed and the solutions were added to $0.5 \mathrm{ml} 1 \mathrm{M}-\mathrm{NaOH}$ (J.T. Baker, Deventer, Holland), $4 \mathrm{ml} 1.2 \mathrm{M}-\mathrm{NaHCO}_{3}$ (Merck), and $\mathrm{pH}$ was raised to 7.0 with $1 \mathrm{M}-\mathrm{NaOH}$. Thereafter, $60 \mathrm{mg}$ pancreatin (porcine, $3 \times$ U.S.P. specifications, Sigma-Aldrich) and $185 \mathrm{mg}$ porcine bile extract (Sigma-Aldrich) was added followed by the capsules, and the solutions were incubated on a shaking water bath $\left(37^{\circ} \mathrm{C}\right)$ with drawing of aliquots $(100 \mu \mathrm{l})$ every $30 \mathrm{~min}$ until the capsules disrupted. For capsules with ${ }^{55} \mathrm{Fe}$ additional aliquots were drawn and centrifuged $(8000 \mathrm{~g}, 10 \mathrm{~min})$ to determine the degree of soluble ${ }^{55} \mathrm{Fe}$ in the digest solution. The time course for the activity of $\left[{ }^{14} \mathrm{C}\right]$ mannitol and ${ }^{55} \mathrm{Fe}$ in the digest solutions was determined by liquid scintillation counting with automatic quench correction with $5 \mathrm{ml}$ InstaGel Plus (PerkinElmer Life and Analytical Sciences).

\section{Statistical analyses}

The sample size was calculated from Fe absorption data from a previous study of ours using similar test meals, i.e. $100 \mathrm{~g}$ fermented oat gruel and a $140 \mathrm{~g}$ whole-wheat roll with butter ${ }^{4}$. To obtain a power of $90 \%$, a calculated sixteen subjects were needed to detect a $2 \%(1 \times \mathrm{SD})$ change in $\mathrm{Fe}$ absorption at a significance level of $0 \cdot 01^{30}$. To ensure enough power in case of dropouts a total of eighteen subjects were included in the study.

Non-haem Fe absorption data were converted to logarithms before the statistical analyses, and the results were reconverted to antilogarithms. All data used for statistical analyses were normally distributed, with variance homogeneity tested by plots of residuals. The non-haem $\mathrm{Fe}$ absorption from the two test meals was compared using a linear mixed model with $\log$ (non-haem Fe absorption) as the dependent variable, meal and serum ferritin as independent fixed variables, and subject as a random effect:

$$
\begin{aligned}
& \log (\text { Non }- \text { haem Fe absorption }) \\
& \quad=\mu\left(\text { meal }_{i}\right)+b \times \text { serum ferritin }_{i}+A\left(\text { subject }_{i}\right)+\varepsilon_{i} .
\end{aligned}
$$

The carry-over effect from the meal with the viable bacteria in the first period to the meal in the second period was analyzed by inserting the alternate meal as a fixed variable in the model.
Data are presented as estimates of least-squares means and differences between estimates of means with $95 \% \mathrm{CI}$.

The statistical analyses were performed with the SAS statistical software package, version 9.1 (SAS Institute Inc., Cary, NC USA), and values were considered significantly different for $P<0 \cdot 05$.

\section{Results \\ Composition of the test meals}

The composition of the test meals as regards the content of minerals, inhibitors of $\mathrm{Fe}$ absorption, and organic acids in the oat gruels are given in Table 1, and the content of all analysed components were similar when comparing the two test meals.

\section{Fe status and non-haem Fe absorption}

All subjects had relatively low Fe stores, but were not anaemic as indicated by their serum ferritin concentrations in the range $13-29 \mu \mathrm{g} / \mathrm{l}$, and $\mathrm{Hb}$ concentrations in the range 116$135 \mathrm{~g} / \mathrm{l}$. The concentrations of the acute phase protein $\alpha_{1^{-}}$ antichymotrypsin $(0.17-0.47 \mathrm{~g} / \mathrm{l})$ were in the normal range, i.e. $<0.6 \mathrm{~g} / \mathrm{l}$ and therefore, serum ferritin was a valid measurement of the Fe status in these subjects ${ }^{31}$.

Determination of ${ }^{55} \mathrm{Fe}$ (III) in the ${ }^{55} \mathrm{Fe}$ (II)-capsules revealed that no significant amount of ${ }^{55} \mathrm{Fe}$ (II) was oxidized to ${ }^{55} \mathrm{Fe}$ (III) in the capsules, as the content of ${ }^{55} \mathrm{Fe}$ (III) was below the detection limit, i.e. $<160 \mathrm{dpm}$ corresponding to less than $4 \%$ conversion of ${ }^{55} \mathrm{Fe}(\mathrm{II})(n 4)$.

The overall non-haem Fe absorption from the fermented oat gruels with and without added viable, lyophilized L. plantarum $299 \mathrm{v}$, respectively, calculated from the mixed linear model analysis is given in Table 2 . The results show no sig-

Table 1. Composition of the test meals (including the whole-wheat roll with butter), and concentrations of organic acids and $\mathrm{pH}$ in the fermented oat gruels

\begin{tabular}{|c|c|c|c|c|}
\hline & \multicolumn{2}{|c|}{$\begin{array}{l}\text { Fermented oat } \\
\text { gruel with viable, } \\
\text { lyophilized } \\
\text { L. plantarum 299v }\end{array}$} & \multicolumn{2}{|c|}{$\begin{array}{l}\text { Fermented oat } \\
\text { gruel with heat- } \\
\text { inactivated } \\
\text { L. plantarum 299v }\end{array}$} \\
\hline & Mean & SD & Mean & SD \\
\hline Energy (MJ) & \multicolumn{2}{|c|}{$2 \cdot 5$} & \multicolumn{2}{|c|}{2.5} \\
\hline Non-haem Fe (mg) & 1.9 & 0.0 & 1.9 & 0.0 \\
\hline 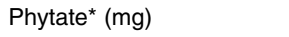 & 234 & 3 & 237 & 2 \\
\hline$(\mu \mathrm{mol})$ & 392 & 5 & 400 & 4 \\
\hline Proanthocyanidinest (mg) & $9 \cdot 2$ & $0 \cdot 2$ & $9 \cdot 3$ & $0 \cdot 2$ \\
\hline Total polyphenols $¥$ (mg) & 43 & 3 & 44 & 1 \\
\hline $\mathrm{Ca}(\mathrm{mg})$ & $29 \cdot 4$ & 0.3 & $29 \cdot 2$ & $0 \cdot 1$ \\
\hline $\mathrm{Zn}(\mathrm{mg})$ & $1 \cdot 0$ & 0.0 & $1 \cdot 0$ & 0.0 \\
\hline Lactic acid $(\mu \mathrm{mol} / \mathrm{g})$ & 92 & 5 & 99 & 6 \\
\hline Acetic acid $(\mu \mathrm{mol} / \mathrm{g})$ & $2 \cdot 8$ & 0.5 & $2 \cdot 3$ & 0.7 \\
\hline Succinic acid $(\mu \mathrm{mol} / \mathrm{g})$ & 0.4 & 0.0 & 0.3 & $0 \cdot 1$ \\
\hline $\mathrm{pH}$ & $3 \cdot 8$ & 0.1 & $3 \cdot 8$ & 0.0 \\
\hline
\end{tabular}

(Mean values and standard deviations for four meals)

${ }^{*}$ Represents individual inositol tri- to hexaphosphates.

$\dagger$ Measured as catechin equivalents.

$\ddagger$ Measured as gallic acid equivalents. 
nificant difference in $\mathrm{Fe}$ absorption from the fermented oat gruel with or without added viable, lyophilized bacteria, and the ratio of Fe absorption from the two meals was not different from unity.

The absorption of ${ }^{55} \mathrm{Fe}$ delivered to the ileum and colon from the enterocoated capsules was below the detection limit, i.e. below $0.1 \%$ of the administered dose.

\section{In vitro digestion of enterocoated capsules}

The enterocoated capsules were stable for $>4 \mathrm{~h}$ when digesting with pepsin at $\mathrm{pH} 2\left(37^{\circ} \mathrm{C}\right)$. The time course for disintegration of the enterocoated capsules during the pancreatin-bile digestion phase $\left(\mathrm{pH} 7,37^{\circ} \mathrm{C}\right)$ following the $4 \mathrm{~h}$ digestion with pepsin showed that the capsules were resistant to the pancreatin-bile solution for about 90-120 min before disruption as shown by release of $\left[{ }^{14} \mathrm{C}\right]$ mannitol (Fig. 1). No difference in the disintegration rate was observed for capsules digested in media of oat gruels with viable bacteria ( $n$ 6) and without bacteria ( $n$ 6), respectively. The release of ${ }^{55} \mathrm{Fe}$ (II) and ${ }^{55} \mathrm{Fe}$ (III) from the capsules ( $n 4$ each) was similar, why the data were pooled, and following $20 \mathrm{~h}, 84$ (SEM 3) \%, ( $n$ 8) of the radioactivity was recovered, of which 63 (SEM 3) $\%$ ( $n$ 8) was in the supernatant after centrifugation $(8000 \mathrm{~g}$, $10 \mathrm{~min})$.

\section{Discussion}

In the present study non-haem Fe absorption was determined from a heat-inactivated lactic acid-fermented oat gruel and from the same gruel where viable, lyophilized $L$. plantarum $299 \mathrm{v}$ (total $10^{11} \mathrm{cfu}$ ) was added. The fermented oat gruel with the viable L. plantarum $299 \mathrm{v}$ was prepared by an addition of viable, lyophilized L. plantarum $299 \mathrm{v}$ to the heat-inactivated lactic acid-fermented oat gruel, which was kept at $4^{\circ} \mathrm{C}$ until serving $1 \mathrm{~d}$ later, allowing for a minimal change in the content of organic acids, minerals, and inhibitors of Fe absorption between the two test gruels (Table 1). This is in contrast to an earlier study performed by our group, where the active fermented oat gruel with $L$. plantarum $299 \mathrm{v}$ was stored at $4^{\circ} \mathrm{C}$ between the two periods ( $25 \mathrm{~d}$ in total), leading to an

Table 2. Non-haem iron absorption from the fermented oat gruels with viable, lyophilized $L$. plantarum $299 \mathrm{v}$ and without $L$. plantarum $299 \mathrm{v}$, respectively

\begin{tabular}{|c|c|c|c|c|}
\hline \multirow[b]{2}{*}{ Non-haem Fe absorption } & \multicolumn{2}{|c|}{$\begin{array}{c}\text { Fermented oat } \\
\text { gruel with viable, } \\
\text { lyophilized } \\
\text { L. plantarum 299v }\end{array}$} & \multicolumn{2}{|c|}{$\begin{array}{l}\text { Fermented oat } \\
\text { gruel with heat- } \\
\text { inactivated } \\
\text { L. plantarum } 299 \mathrm{v}\end{array}$} \\
\hline & Mean & $95 \% \mathrm{Cl}$ & Mean & $95 \% \mathrm{Cl}$ \\
\hline${ }^{59} \mathrm{Fe}$ from meal $(\%)^{*}$ & 1.4 & $0.9,2 \cdot 2$ & 1.3 & $0.9,2 \cdot 0$ \\
\hline $\begin{array}{l}\text { Test meal:control meal† } \\
{ }^{55} \mathrm{Fe} \text { from enterocoated } \\
\text { capsules }(\%)\end{array}$ & \multicolumn{2}{|c|}{$<0.1$} & \multicolumn{2}{|c|}{$<0.1$} \\
\hline
\end{tabular}

* Geometric means of least squares estimates from the mixed linear model analysis with $95 \% \mathrm{Cl}(n 18)$.

$\dagger$ Geometric means of estimates of differences from the mixed linear model analysis with $95 \% \mathrm{Cl}(n 18)$.

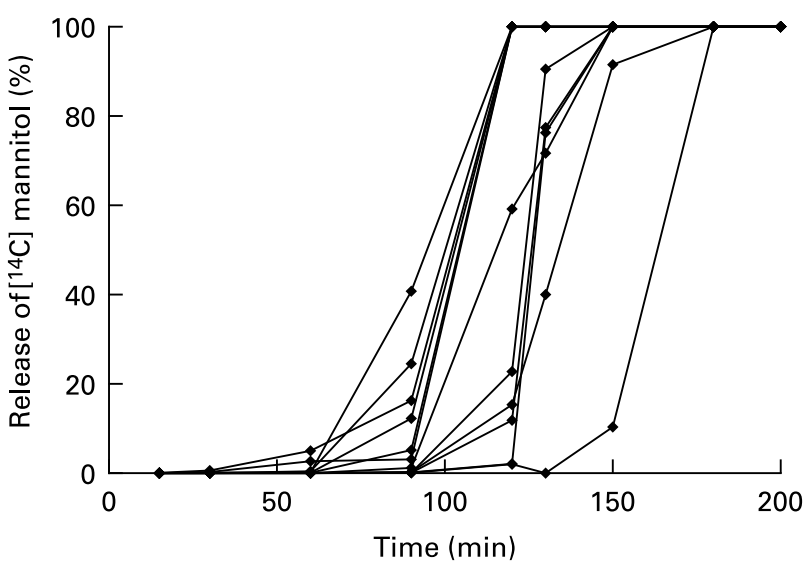

Fig. 1. Time course for disintegration of enterocoated capsules during digestion with pancreatin-bile $\left(\mathrm{pH} 7,37^{\circ} \mathrm{C}\right)$ after $4 \mathrm{~h}$ pepsin digestion $\left(\mathrm{pH} 2,37^{\circ} \mathrm{C}\right)$ in oat gruel medium with or without viable L. plantarum $299 \mathrm{v}$, respectively ( $n$ 6, each). The disintegration was demonstrated by the release of $\left[{ }^{14} \mathrm{C}\right] \mathrm{man}$ nitol from the capsules into the digest solution, and there was no difference between gruels with and without viable bacteria. The lines represent the disruption of the individual capsules.

increase in the concentration of lactic acid of $19 \%$ during this period ${ }^{4}$.

The non-haem Fe absorption in the present study was 1.4 and $1.3 \%$ from the heat-inactivated fermented oat gruels with and without viable L. plantarum 299v, respectively (Table 2). The aforementioned study indicated an effect of the viable $L$. plantarum $299 \mathrm{v}$ on $\mathrm{Fe}$ absorption beyond that caused by the lactic acid produced during the fermentation ${ }^{4}$. However, we were not able to confirm this effect in the present study with viable, lyophilized bacteria.

To be able to ensure detection of even small effects of $\mathrm{L}$. plantarum $299 \mathrm{v}$ on $\mathrm{Fe}$ absorption a very low Fe absorption ratio was chosen by constructing the meals with a high content of phytate from the dose-response curve for phytate in relation to $\mathrm{Fe}$ absorption ${ }^{32}$. Furthermore, no enhancers were added. This has been shown to be a relevant level of phytate, as we in the previous study were able to significantly detect small differences in $\mathrm{Fe}$ absorption from the same basic meals ${ }^{4}$. Previous studies on $\mathrm{Fe}$ absorption from oat porridge meals with similar contents of phytate but also containing ascorbic acid as an enhancer have also shown relatively low $\mathrm{Fe}$ absorption values of $3 \cdot 2-4.0 \%$, which would have reach levels comparable to this study if no inhibitors were $\operatorname{added}^{33,34}$.

From the putative effect of viable L. plantarum $299 \mathrm{v}^{4}$ and the hypothesis that the colon may function as a significant site of $\mathrm{Fe}$ absorption in response to stimulation by pre- and probiotics, especially during $\mathrm{Fe}$ depletion ${ }^{9,13}, \mathrm{Fe}$ absorption was selectively determined from the distal part of the small intestine and the colon using enterocoated capsules containing ${ }^{55} \mathrm{Fe}$ as a tracer for $\mathrm{Fe}$ absorption. To our knowledge this is the first study to measure $\mathrm{Fe}$ absorption from a meal specifically in the distal part of the human small intestine and colon since only one study describes the attempt to measure Fe absorption from the human colon by infusion of radiolabelled ferrous and ferric chloride solutions directly through a sigmoidoscope in non-anaemic subjects ${ }^{35}$. The stability of the capsules was tested by in vitro digestion. The capsules were 
stable for more than $4 \mathrm{~h}$ under gastric conditions, and disintegration of the capsules under conditions mimicking the lumen in the small intestine did not occur until after 90-120 min (Fig. 1), corresponding roughly to the transit time for the luminal content from pylorus to ileum after a meal. This is in accordance with Jacobsen and co-workers, who determined the disintegration of enterocoated tablets (cellulose acetate phthalate) containing $\mathrm{BaSO}_{4}$ by fluoroscopy in patients who had undergone ileal resection ${ }^{24}$. The tablets disintegrated in the most distal part of the remaining ileum or caecum and in only three of fourteen patients did disintegration not occur within the $8 \mathrm{~h}$ after ingestion followed by fluoroscopy. Furthermore, as $84 \%{ }^{55} \mathrm{Fe}$ was recovered from the disintegrated capsules after $20 \mathrm{~h}$ of which $63 \%$ was in the supernatant after centrifugation, these data clearly indicate that $\mathrm{Fe}$ released from the capsules will mix with $\mathrm{Fe}$ in the luminal content and be potentially available for absorption. Together, these observations strongly indicate that the enterocoated capsules with ${ }^{55} \mathrm{Fe}$ disintegrated and released their content of ${ }^{55} \mathrm{Fe}$ in the ileum, and ${ }^{55} \mathrm{Fe}$ thereby acted as a tracer for Fe absorption in the ileum and colon.

Very little is known about the mechanisms of Fe absorption in the large intestine, but there seems to be a preference for ferrous $\mathrm{Fe}^{35}$ as in the proximal small intestine, and as the expression of the apical ferric reductase, duodenal cytochrome $\mathrm{B}$ (DcytB), involved in reduction of ferric to ferrous $\mathrm{Fe}$ in the duodenum is significantly reduced with a downward gradient along the length of the gut $^{8}$, the uptake is dependent on other factors, such as lowering of luminal $\mathrm{pH}$ by fermentation $^{13}$. It is however uncertain whether both oxidation states of $\mathrm{Fe}$ are absorbable in the colon. Therefore, to ensure that if any $\mathrm{Fe}$ absorption was to occur distally it would not remain undetected due to a wrong oxidation state of the $\mathrm{Fe}$ used as tracer, the $\mathrm{Fe}$ in the enterocoated capsules were given as both ferrous and ferric Fe. However, no absorption of ${ }^{55} \mathrm{Fe}$ was observed from either of the test meals, indicating that there was no absorption of $\mathrm{Fe}$ in the distal intestine.

An explanation for the lack of effect of the viable L. plantarum $299 \mathrm{v}$ in the present study could be that the bacteria were not in a comparable active state, as they were added in a lyophilized condition to a cold product to avoid any changes in composition of the test gruel. This is in sharp contrast to the earlier study ${ }^{4}$ where the lactobacillus was metabolically active during the fermentation process and not heat-inactivated but stored cold until serving.

A subsequent analysis of the activity of the bacteria in an oat gruel fermented with $L$. plantarum $299 \mathrm{v}$ similar to the one used in the aforementioned study ${ }^{4}$ has been undertaken and compared with the activity of the bacteria in the present heat-inactivated oat gruel with added lyophilized L. plantarum $299 \mathrm{v}$. The result showed that the metabolic activity at $37^{\circ} \mathrm{C}$ (lowering of $\mathrm{pH}$ in an oat based medium) was retarded by approximately $1 \mathrm{~h}$ from lactic acid bacteria that were added to the oat gruel in a lyophilized form (data not shown). Since no $\mathrm{Fe}$ absorption seems to occur in the ileum and colon, it could be hypothesized that the bacteria needs to be in an active stage in the most proximal small intestine to exert a direct effect on $\mathrm{Fe}$ absorption beyond the one caused by the organic acids present in the oat gruel. The activity test indicates that the lactobacillus added in a lyophilized form less quickly reaches an active stage, which potentially could affect the metabolic activity of the bacteria in the duodenum and thereby explain the lack of effect of $L$. plantarum $299 \mathrm{v}$ in this study. Furthermore this would support the conclusion in the aforementioned study ${ }^{4}$ that a specific effect of viable L. plantarum $299 \mathrm{v}$ contributed to the increased $\mathrm{Fe}$ absorption. The effect of the gastric residence has though not been taken into account, and the lag phase for this adaptation is not known for either of the formulations tested.

Although the subjects had low Fe stores, i.e. serum ferritin $<30 \mu \mathrm{g} / \mathrm{l}$, the Fe absorption from the fermented oat gruels was very low, $1.3-1.4 \%$, corresponding to $0.02-0.03 \mathrm{mg} \mathrm{Fe}$ in total amounts. This very low absorption was presumably due to the presence of high amounts of phytate and phenolic compounds in the meals (Table 1), and the lack of enhancers such as ascorbic acid, which was deliberately avoided in this study, as we wished a low basal absorption to ensure detection of even small effects of viable L. plantarum 299v on Fe absorption. Previous studies on Fe absorption from oat porridge meals with similar contents of phytate have also shown relatively low $\mathrm{Fe}$ absorption values of $3 \cdot 2-4 \cdot 0 \%{ }^{33,34}$. In both studies, the $\mathrm{Fe}$ absorption was about double that found in the present study, most likely due to the serving of orange juice, corresponding to $70 \mathrm{mg}$ ascorbic acid, with these meals.

In conclusion, the addition of viable, lyophilized L. plantarum $299 \mathrm{v}$ to a heat-inactivated lactic acid-fermentedoat gruel did not affect non-haem $\mathrm{Fe}$ absorption from a low Fe bioavailability meal, and no absorption of $\mathrm{Fe}$ occurred in the ileum and the colon, at least in young women with low Fe status.

\section{Acknowledgements}

We thank Inge Rasmussen, Hanne Lysdal Petersen, and Leif Jakobsen, Department of Human Nutrition, University of Copenhagen, Frederiksberg, Denmark, and Susanne Svalling, Department of Clinical Physiology and Nuclear Medicine, The National University Hospital, Copenhagen, Denmark, for providing excellent technical assistance. This work was funded by The Ministry of Science, Technology, and Innovation, Denmark, and Vinnova, Sweden.

\section{References}

1. Derman DP, Bothwell TH, Torrance JD, Bezwoda WR, Macphail AP, Kew MC, Sayers MH, Disler PB \& Charlton RW (1980) Iron absorption from maize (Zea mays) and sorghum (Sorghum vulgare) beer. Br J Nutr 43, 271-279.

2. Gillooly M, Bothwell TH, Torrance JD, Macphail AP, Derman DP, Bezwoda WR, Mills W, Charlton RW \& Mayet F (1983) The effects of organic acids, phytates and polyphenols on the absorption of iron from vegetables. Br J Nutr 49, 331-342.

3. Hallberg L \& Rossander L (1982) Absorption of iron from western-type lunch and dinner meals. Am J Clin Nutr 35, 502-509.

4. Bering S, Suchdev S, Sjøltov L, Berggren A, Tetens I \& Bukhave K (2006) A lactic acid fermented oat gruel increases non-haem iron absorption from a phytate rich meal in healthy women of childbearing age. Br J Nutr 96, 80-85.

5. Sandberg A-S \& Andersson H (1988) Effect of dietary phytase on the digestion of phytate in the stomach and small intestine of humans. J Nutr 118, 469-473. 
6. Bergqvist SW, Sandberg AS, Andlid T \& Wessling-Resnick M (2005) Lactic acid decreases Fe(II) and Fe(III) retention but increases $\mathrm{Fe}(\mathrm{III})$ transepithelial transfer by Caco-2 cells. J Agric Food Chem 53, 6919-6923.

7. Liljeberg H \& Bjorck I (1998) Delayed gastric emptying rate may explain improved glycaemia in healthy subjects to a starchy meal with added vinegar. Eur J Clin Nutr 52, 368-371.

8. Miret S, Simpson RJ \& McKie AT (2003) Physiology and molecular biology of dietary iron absorption. Anпu Rev Nutr 23, 283-301.

9. Bouglé D, Vaghefi-Vaezzadeh N, Roland N, Bouvard G, Arhan P, Bureau F, Neuville D \& Maubois JL (2002) Influence of short-chain fatty acids on iron absorption by proximal colon. Scand J Gastroenterol 37, 1008-1011.

10. Campos MS, Gómes-Ayala AE, López-Aliaga I, Pallarés I, Hartiti S, Alférez MJM, Barrionuevo M, Rodríguez-Matas MC \& Lisbona F (1996) Role of the proximal colon in mineral absorption in rats with and without ferropenic anemia. Nutr Res 16, $1529-1543$

11. Johnston KL, Johnson DM, Marks J, Srai SK, Debnam ES \& Sharp PA (2006) Non-haem iron transport in the rat proximal colon. Eur J Clin Invest 36, 35-40.

12. Demigne C, Levrat MA \& Remesy C (1989) Effects of feeding fermentable carbohydrates on the cecal concentrations of minerals and their fluxes between the cecum and blood plasma in the rat. $J$ Nutr 119, 1625-1630.

13. Yeung CK, Glahn RP, Welch RM \& Miller DD (2005) Prebiotics and iron bioavailability - is there a connection? J Food Sci 70, R88-R92.

14. Sakai K, Ohta A, Shiga K, Takasaki M, Tokunaga T \& Hara H (2000) The cecum and dietary short-chain fructooligosaccharides are involved in preventing postgastrectomy anemia in rats. J Nutr 130, 1608-1612.

15. Lopez HW, Levrat-Verny MA, Coudray C, Besson C, Krespine V, Messager A, Demigne C \& Remesy C (2001) Class 2 resistant starches lower plasma and liver lipids and improve mineral retention in rats. J Nutr 131, 1283-1289.

16. Coudray C, Bellanger J, Castiglia-Delavaud C, Remesy C, Vermorel M \& Rayssignuier Y (1997) Effect of soluble or partly soluble dietary fibres supplementation on absorption and balance of calcium, magnesium, iron and zinc in healthy young men. Eur J Clin Nutr 51, 375-380.

17. van den Heuvel EG, Schaafsma G, Muys T \& van Dokkum W (1998) Nondigestible oligosaccharides do not interfere with calcium and nonheme-iron absorption in young, healthy men. Am J Clin Nutr 67, 445-451.

18. Oda T, Kado-oka Y \& Hashiba H (1994) Effect of Lactobacillus acidophilus on iron bioavailability in rats. J Nutr Sci Vitaminol (Tokyo) 40, 613-616.

19. Wienk KJ, Marx JJ \& Beynen AC (1999) The concept of iron bioavailability and its assessment. Eur J Nutr 38, 51-75.

20. Molin G (2001) Probiotics in foods not containing milk or milk constituents, with special reference to Lactobacillus plantarum 299v. Am J Clin Nutr 73, 380S-385S.
21. Johansson ML, Molin G, Jeppsson B, Nobaek S, Ahrne S \& Bengmark S (1993) Administration of different Lactobacillus strains in fermented oatmeal soup: in vivo colonization of human intestinal mucosa and effect on the indigenous flora. Appl Environ Microbiol 59, 15-20.

22. Bukhave K, Sørensen AD \& Hansen M (2001) A simplified method for determination of radioactive iron in whole-blood samples. J Trace Elem Med Biol 15, 56-58.

23. Molin N, Albertsson KE, Bengmark S \& Larsson K (1991) Nutrient composition and method for the preparation thereof. US patent no 5190 755, European patent no 0415941, Sweden patent no 8800822-2, Australia patent no 620858, Norway patent no 178321 , Denmark patent no 171057 , Singapore patent no 38358, Finland patent no 98192, Japan patent no 2139930 .

24. Jacobsen O, Hojgaard L, Hylander ME, Wielandt TO, Thale M, Jarnum S \& Krag E (1985) Effect of enterocoated cholestyramine on bowel habit after ileal resection: a double blind crossover study. BMJ 290, 1315-1318.

25. Carlsson NG, Bergman EL, Skoglund E, Hasselblad K \& Sandberg AS (2001) Rapid analysis of inositol phosphates. J Agric Food Chem 49, 1695-1701.

26. Scalbert A (1999) Quantitative methods for the estimation of tannins in plant tissues. In Plant polyphenols: synthesis, properties, significance, pp. 259-280 [RW Hemingway and PE Laks, editors]. New York: Plenum Press Corp.

27. Richardson AJ, Calder AG, Stewart CS \& Smith A (1989) Simultaneous determination of volatile and non-volatile acidic fermentation products of anaerobes by capillary gas chromatography. Lett Appl Microbiol 9, 5-8.

28. Hallberg L (1980) Food iron absorption. In Iron, pp. 116-133 [JD Cook, editor]. New York: Churchill Livingstone.

29. Stevens HM (1956) The separation of iron valencies by paper chromatography. Anal Chim Acta 15, 538-542.

30. Altman DG (1991) Practical statistics for medical research. London: Chapman \& Hall/CRC.

31. Wieringa FT, Dijkhuizen MA, West CE, Northrop-Clewes CA \& Muhilal (2002) Estimation of the effect of the acute phase response on indicators of micronutrient status in Indonesian infants. $J$ Nutr 132, 3061-3066.

32. Brune M, Rossander-Hultén L, Hallberg L, Gleerup A \& Sandberg A-S (1992) Iron absorption from bread in humans: inhibiting effects of cereal fiber, phytate and inositol phosphates with different numbers of phosphate groups. J Nutr 122, 442-449.

33. Larsson M, Rossander-Hulten L, Sandstrom B \& Sandberg A-S (1996) Improved zinc and iron absorption from breakfast meals containing malted oats with reduced phytate content. $\mathrm{Br} J$ Nutr 76, 677-688

34. Rossander-Hulten L, Gleerup A \& Hallberg L (1990) Inhibitory effect of oat products on non-haem iron absorption in man. Eur J Clin Nutr 44, 783-791.

35. Ohkawara Y, Bamba M, Nakai I, Kinka S \& Masuda M (1963) The absorption of iron from the human large intestine. Gastroenterol 44, 611-614. 